\title{
Social network of children with cronic disease: knowledge and practice of nursing
}

\author{
Rede social de crianças com doença crônica: conhecimento e prática de enfermeiros \\ Red social de niños con enfermedad crónica: conocimiento y práctica de enfermeras
}

Maria Helena do Nascimento Souza' ORCID: 0000-0003-2230-3048

Vanessa Medeiros da Nóbrega" ORCID: 0000-0002-1042-8487

Neusa Collet" ORCID: 0000-0002-4795-0279

'Universidade Federal do Rio de Janeiro. Rio de Janeiro, Rio de Janeiro, Brazil.

"Universidade Federal da Paraíba. João Pessoa, Paraíba, Brazil

How to cite this article:

Souza MHN, Nóbrega VM, N Collet. Social network of children with cronic disease: knowledge and practice of nursing. Rev Bras Enferm. 2020;73(2):e20180371. doi: http://dx.doi.org/10.1590/0034-7167-2018-0371

\section{Corresponding Author:}

Maria Helena do Nascimento Souza E-mail:mhnsouza@yahoo.com.br

EDITOR IN CHIEF: Dulce Aparecida Barbosa ASSOCIATE EDITOR: Cristina Parada

Submission: 07-03-2018

Approval: 07-23-2019

\begin{abstract}
Objectives: To identify the knowledge and practice of primary care nurses about the social network approach for families of children with chronic diseases. Methods: Qualitative research, conducted by means of interviews with 23 family health nurses, from one municipality in Paraíba and one in Rio de Janeiro, from June to July of 2017. The data were interpreted using thematic analysis. Results: Social network meant institutional support offered by services outside the unit, and socioeconomic problems involved the family context. In practice, nurses find it difficult to provide comprehensive care and establish ties with families. When referring to other professionals, a weakness in the counter-referral to the family health unit is found. Final considerations: Some gaps were found regarding the knowledge and practice of nurses regarding the social network approach, which requires professional training to strengthen social relationships and the necessary support for families of children with chronic diseases.

Descriptors: Social Networking; Chronic Disease; Child Health; Primary Health Care; Pediatric Nursing.
\end{abstract}

\section{RESUMO}

Objetivos: identificar o conhecimento e a prática de enfermeiros de atenção primária sobre a abordagem de rede social de famílias de crianças com doenças crônicas. Métodos: pesquisa qualitativa realizada mediante entrevista com 23 enfermeiros de saúde da família de um município da Paraíba e um do Rio de Janeiro, no período de junho a julho de 2017. Os dados foram interpretados pela análise temática. Resultados: rede social significou suporte institucional oferecido por serviços externos à unidade e questões socioeconômicas implicadas no contexto familiar. Na prática os enfermeiros encontram dificuldades para prestar cuidado integral e estabelecer vínculo com as famílias. Quando encaminhadas para outros profissionais, existe fragilidade na contrarreferência à unidade saúde da família. Considerações finais: há lacunas no conhecimento e na prática dos enfermeiros sobre abordagem de rede social, necessitando de capacitação profissional para o fortalecimento das relações sociais e do suporte necessário às famílias de crianças com doenças crônicas. Descritores: Rede Social; Doença Crônica; Saúde da Criança; Atenção Primária à Saúde; Enfermagem Pediátrica.

\section{RESUMEN}

Objetivos: identificar el conocimiento y la práctica de las enfermeras de atención primaria sobre el enfoque de redes sociales de las familias de niños con enfermedades crónicas. Métodos: investigación cualitativa realizada a través de una entrevista con 23 enfermeras de salud familiar de un municipio de Paraíba y Río de Janeiro, de junio a julio de 2017. Los datos fueron interpretados por análisis temático. Resultados: red social significaba apoyo institucional ofrecido por servicios fuera de la unidad y problemas socioeconómicos implicados en el contexto familiar. En la práctica, a las enfermeras les resulta difícil brindar una atención integral y establecer lazos con sus familias. Cuando se refieren a otros profesionales, encuentran fragilidad en la contrarreferencia a la unidad de salud familiar. Consideraciones finales: existen lagunas en el conocimiento y la práctica de las enfermeras sobre el enfoque de redes sociales que requieren capacitación profesional para fortalecer las relaciones sociales y el apoyo necesario para la familia de niños con enfermedades crónicas.

Descriptores: Red Social; Enfermedad Crónica; Salud del Niño; Atención Primaria a la Salud; Enfermería Pediátrica. 


\section{INTRODUCTION}

Chronic diseases in children are major public health problems, and they are generally related to multiple causes, such as those from a biological, psychological, or cognitive basis ${ }^{(1)}$.

A study conducted in the United States revealed that $19.4 \%$ of children, from 3 to 17 years of age, present some special needs; $22.3 \%$ had at least one chronic condition, and $19.7 \%$ had more than one ${ }^{(2)}$. A Brazilian national survey showed a prevalence of chronic disease of $9.1 \%$ among children aged zero to four years, $9.7 \%$ between six to 13 years, and $11 \%$ among adolescents aged 14 to 19 years ${ }^{(3)}$, revealing that the prevalence of this problem is high and directly associated with the increase in the age of the group.

Chronic disease in children begins gradually, and can present with a long or indefinite duration, which requires continuous home and hospital level care. In addition, changes in lifestyle occur, and there is a constant need for intervention by health professionals, due to the problems caused by the disease $e^{(1,4)}$. The children with chronic disease can present some functional limitations, medication dependence, need for special feeding techniques, and the need for a technological device or direct assistance in health services. Based on these issues, these children have been called Children with Special Health Needs - CSHCN ${ }^{(5)}$.

In relation to the conditions of life of children with chronic diseases, evidence shows that the everyday family can be marked by several alterations, such as: anxiety, concern of parents and relatives, distress, detachment of family members, overload of caregivers, hospitalizations, conflicts, need for home adequacy, decrease of family income, stress, fear, and social isolation, among other issues. These alterations are more accentuated when the family cannot count on a social network for the children's care ${ }^{(6-7)}$.

A social network is understood as a "set of interpersonal relations that determine the person characteristics, such as habits, costumes, beliefs and values", and, from such a network, the individual can receive emotional and material help, services, and information. According to their nature, social networks can be: primary, characterized by family, friendship, or neighborhood relationships, or, secondary, represented mainly by people linked to the health, education or social assistance institutions(8).

In the field of health, but specifically in nursing care, it is increasingly perceived that interventions that emphasize only the biomedical model have been insufficient for understanding the real needs of the population. Therefore, studies of the sociocultural conditions, such as the knowledge of the social support network, become necessary in order to extend support both to the lived experience of the family receiving care, as well as to manage the possibilities for the nursing care of individuals with chronic disease ${ }^{(9-10)}$.

Studies tackled the importance of social networking support for families of children with chronic diseases, demonstrating that a strengthened network contributed to coping with the chronic condition $^{(5,7,11-12)}$. From this perspective, it is worthwhile to consider health professionals, especially nurses, to offer or support the necessary needs for care for these children in the various levels of health care, by means of a relationship of mutual trust that favors coping with adversities and therapeutic events ${ }^{(13)}$.
Despite the significant increase in research on the relevance of social networks related to the care of individuals with chronic disease, gaps remain in the literature that refer to the knowledge and practice of nurses in the primary care network, related to the social network thematic approach in the care of children who live with chronic disease.

Based on this, the question is: What is the knowledge and practice of primary care nurses on the social network approach for families of children with chronic diseases?

\section{OBJECTIVES}

To identify or understand the practice of primary care nurses using the social network approach for families of children with chronic diseases.

\section{METHODS}

\section{Ethical aspects}

This research was approved by the Ethics Committee of the University of Anna Nery- EEAN, the Ethics Committee of the Municipal Secretary of Health and Civil Defense of Rio de Janeiro, and the annuity of the Municipal Secretary of Health of João Pessoa, in attendance à Resolution No.466/12, which provides rules for research with human beings. All participants signed The Terms of Free and Informed Consent form.

\section{Theoretical-methodological framework and study type.}

This was descriptive, qualitative research grounded in theories based on the theoretical-methodological reference of Sanicola's social network ${ }^{(8)}$.

Studies about a network or social support are increasingly being incorporated into the field of health, and other areas involved with care that experience a situation of vulnerability. A social network approach makes it possible to understand who are the people and institutions that are present in the life of this individual, which is the protection role that the various members of the network perform, and how community articulation is given in search of support, facing the demand of $\operatorname{care}^{(8)}$.

\section{Methodological procedures}

\section{Study setting and data source}

This research was conducted with 23 nurses of family health teams, who were working in João Pessoa/Paraiba or Rio de Janeiro/Rio de Janeiro, selected by following these critical criteria for inclusion: being a nurse, working in clinical practice in health family teams during the data collection period, between June and July of 2017. Nurses on sick leave or vacation were excluded.

The participant selection occurred in an intentional manner in the family health units of two municipalities of João Pessoa and Rio de Janeiro, which constituted the research setting, entitled:"Utilization of the methodological reference of social networks for clinical care of primary care nurses with families of children with chronic diseases". 


\section{Data collection and organization}

Data collection was initiated after presentation of the research objectives, and signing of the Terms of Free and $\mathrm{i}=$ Informed Consent form.

A semi-structured interview was administered, based on a guide driven by the questions: What do you understand about social network for the family of children with chronic disease? In what manner do you address this issue within your care practice?

The interviews were: conducted in a place reserved in the participating health unit, lasted from 25 to 40 minutes, and recorded in MP3 format. Data collection was finalized after all the participants within the research setting were interviewed, respecting all the criteria of inclusion and saturation ${ }^{(14)}$ of information. Thus, interviews were conducted with 16 nurses from the family health teams in the municipality of João Pessoa, and seven nurses from teams in the city of Rio de Janeiro.

\section{Data analysis}

The statements were transcribed in their entirety and the content was submitted to thematic analysis ${ }^{(14)}$ developed according to the stages: pre-analysis, in which a comprehensive reading of the selected material is conducted to go beyond the statements and facts, to analyze what was implicit, and to identify thematic units; and development of an interpretive synthesis that allowed the identification of central themes that were grouped into empirical categories.

During this process of analysis, two empirical categories were developed: knowledge of the social network for families of children with chronic disease, and, linking of the health care network services with the establishment of social network connections, to provide support.

To guarantee anonymity, the excerpts from the statements were identified by the letters EJP and ERJ, the first letter corresponding to the category of nurse, and the other corresponding to the municipality where the nurse performed his or her professional activities. These three letters were followed by Arabic numbers, according to the order of the interviews.

\section{RESULTS}

The first category, Knowledge of the social network for families of children with chronic disease, demonstrated the nurses' understanding of the social network theme. The second category, Linking of the health care network services with the establishment of social network connections, to provide support, included the limitations perceived by the nurses in the practical care for families of children with chronic disease, as well as implications for the continuity of care for this population.

\section{Knowledge of the social network for families of children with chronic disease}

This category showed that the participants, at first, ignored the social network term, as a question to be approached during the daily primary care practice, and made assumptions about what should occur:
Look, I think I don't know much. I understand it would be a network based on the patient's need. For example, in the case of the diabetic child, we have to know what she will need, beyond purely medical or nursing care. We have to see if the children have access to leisure, where they live, what their parents are like, if their families are engaged in their treatment, if they understand what they have, the type ofdisease... (EJP3)

We never use this term, social network. I think it would be a knowledge of the problems that the family has ..., not just the child himself/herself. (EJP6)

While providing care, we do not explain much about social networks. Sometimes we have difficulty for not having the knowledge of talking about social networks. (ERJ17)

The participants mentioned being more familiar with the term, social support. The term, social network, on the other hand, meant the presence of referral centers or institutions outside the family health unit, which can contribute to improving the quality of care provided, according to the child's need or chronic condition:

[...] we have patients who are wheelchair users, we have children with diabetes, neurological problems, autism ..., who are part of this support group [...]Foundation for Integrated Disability Support Center [FUNAD], Psychosocial Care Centers [CAPS], Social Assistance Reference Centers [CRAS], Family Health Support Centers [NASF], the universities, they help us, they are our partners ..... (EPJ10)

The nurses from these institutions expect to be able to rely on support, or support necessary for care that, in their perception, cannot be offered within the context of the family health unit:

Social networking would be a Referral Center, which would help the health unit staff to support this mother, [...] a support that staff in certain cases cannot provide. (EJP11)

It is as if it were a Reference Center that the mother can seek, for assistance, or in case of doubts or need for support. (ERJ23)

The primary care nurses also explained that the lack of contact with families, who have a child with chronic disease, contributes to the lack of knowledge of the social network and difficulty in monitoring the child.

I have little contact with this diabetic child. She [mother] said she is following up in the specialized service. [...] I asked her to come today and she didn't come. (EJP1)

[...] [the families] do not come back, they are interested in solving those problems momentarily, they have difficulty understanding the continuity of care. (ERJ17)

There was a child who has Down's Syndrome [...]. The mother does not come, we have to search ... Visiting this child's home is very difficult, even the access is very difficult, because she stays with her sister, and the sister does not answer the phone call or is not at home. [...]. It was very hard and I'm not following her anymore. (ERJ18)

Most nurses understand that the social network approach coincides with the knowledge of the socioeconomic and environmental 
context of the family of children with chronic disease, and how interfamilial relationships occur:

Go to the house, see the environment, observe who the caregiver is, observe the mother, talk to the mother, but often the mother is not the caregiver. The mother goes to work, the grandmother stays, or it is the sister-in-law or the neighbor. (EJP12)

Social network are the socioeconomic conditions of the family, which include health and education. (EJP13)

I imagine it is the conviviality of this child in general, regardless of the chronic condition or not. Her bond with her parents, siblings, and her integration into the social environment. [...] And I try to see how this interaction is. (ERJ21)

[...] I addressed the issue of family structure, how they organized themselves, how children were cared for, how they felt working and living in the house, and having shared care with the husband. (ERJ20)

\section{Linking of the health care network services with the estab- lishment of social network connections, to provide support}

In this category, the results showed that the services of the various levels of the health care network should be articulated, facilitating the establishment of a partnership between professionals. While developing some actions to connect the family network, they still find it very difficult to establish these connections:

These supports would be interconnected places; for example, primary care with a secondary care, with tertiary care that can improve care for this child [...]. So, this team really has to be linked with several other professionals, in order to try to maintain adequate care [...] Here, the networks are interconnected, but there is still a lot of delay, a lot of difficulty. (ERJ17)

The cases of obesity we have tried to treat and care for here. We also have activities with schools to try to address this issue. My concern is to show that we are one of several possible points and that the healthcare industry alone will not address a problem that is sometimes structural. (ERJ22)

There is a child who, besides being underweight, is short. [...] Visualizing her social context, we go looking for partners. First, we contacted the NASF social worker, but not being satisfied with this performance, the health worker and I went after CRAS. [...]. She is receiving a basic food basket and, other than that, we get a place for her at the school where our team operates. [...] I think that the sensitivity, to realize that it is not just a matter of disease, there are other needs. Therefore it is necessary to look for partners. (EJP15)

The lack of professional training to provide nursing care to children with chronic conditions was pointed to as an important weakness for the continuity of care:

[...] I still think that we, in primary care, are not prepared to receive these chronic children, as we should be. (EJP16)

It was also evidenced that, in daily care practices, when verifying that the demand for care of children with chronic diseases transcends their ability to provide care, nurses seek, in some manner, to ensure the immediate referral of such children to other professionals, in order to ensure they receive necessary assistance.

With the hearing impaired child, [...] we refer her to the specificity center for hearing problems. The mother got a cochlear implant for both children. So, that was this kind of support, we referred to the specialty center and to care with a speech therapist. (ERJ18)

This child with diabetes is a five-year-old, whose mother came complaining that she was very thirsty, drinking a lot of water. Examinations were requested and we referred her to a pediatric endocrinologist. (EJP5)

If a specialized assessment is required, referral is made by SISREG [System of Regulatory Centers]. (ERJ22)

On the other hand, the nurses explained that they face difficulties with providing comprehensive care for children with chronic diseases, because they are preferably treated by the unit's team physician.

Here, we have children [with chronic illnesses] who sometimes go outside of our ability to monitor them, and go into the team physician's purview. (ERJ17)

We have some children, but I see a certain difficulty, because the ACS [Community Health Agent], who makes the appointments, thinks that in these cases the medical consultation need to be prioritized [...]. So, I know that there are children with microcephaly, diabetes, and many other problems, but I see that there is a restriction on scheduling appointments with the nurse. [...] here, she [mother] always prioritizes the medical care. (ERJ21)

Because, there is very little contact with these cases [of children with chronic diseases], they usually come to the physicians. Sometimes they are seen by the physicians and I don't even know. (EJP6)

Before referring the child to other levels of the health care network, some participants expressed concern about performing procedures during the nursing consultation and providing guidance to the family regarding childcare at home and promotion measures of health.

The child with autism, for example, if I see that this child is very pale, I request the tests for iron supplementation. For another child who also has autism, and who is also thin, I provide information regarding weight gain, food, and a referral to the nutritionist. (EJP2)

I guide the care that the mother must have: smoke, dust, with what is inside and around the house, regarding hygiene. (EJP9)

I helped her understand, that she [mother] should keep in touch there [with the hospital] and that she would have to keep coming to groups and appointments here at the unit. (ERJ19)

In terms of the possibility of referring children with chronic diseases to other services, the participating nurses found difficulties within the counter-referral system of these services to the family health unit, revealing the lack of articulation between the levels of network care. 
[...] we don't have that feedback, we don't have the counterrefererral. Many times the information we get is when the family comes, or when the health agent comes to visit, where he gives us the feedback. (EJP10)

Our network today is still fragile. [...] Sometimes I get some counterreferral from hospitals, sometimes not. It has a lot of fragility. (EJP8)

Another aggravating problem relates to the lack of a network set up in the municipalities from which professionals know where to refer children and are assured that they will be attended to.

Sometimes I do not know where to go. For example, if I receive a child with esophageal or rectal cancer ... Where do I refer that family for ostomy care? So, sometimes we don't have that flow of information. It is very flawed. (ERJ17)

\section{DISCUSSION}

With regard to regarding the social network theme, participants showed different levels of comprehension. At first, the professionals demonstrated that they were unaware of the meaning of the terminology, "social network", and for this reason, they did not use this tool during the care of children with chronic diseases.

Corroborating these findings, studies on the importance of health professionals considering sociocultural conditions in addition to biological factors, in their care practice, showed that the intervention on the social network of those receiving care is not yet the focus of attention of these professionals ${ }^{(10-11)}$.

In the participants' perception, the term "social network" was identified as social support, or as aspects related to the socioeconomic and environmental context of families of children with chronic diseases. Although some studies do not make a distinction between the concepts of social network and social support, assuming that having social relations is equivalent to obtaining support from the network ${ }^{(12,15)}$, others presuppose independence between these terms $s^{(6-8)}$, since the social network may or may not have the necessary support to confront a problem.

From this perspective, the importance of health professionals knowing the type of network and social support that families of children with chronic diseases can count on in their daily relationship with family, neighbors, friends, schoolmates or members of public and private institutions is emphasized ${ }^{(6,9,13,16)}$. The action of these professionals can contribute to the expansion and strengthening of social support networks, by reducing family isolation, creating new bonds and effective assistance in the care of children with chronic conditions, improving their quality of life at the beginning and throughout the course of the disease $\mathrm{e}^{(13,16-17)}$.

According to the study participants, family health units, in most cases, are unable to provide the necessary support to confront the care demands of children with chronic diseases, corroborating other studies that showed that nurses stated this same difficulty ${ }^{(5,11,18)}$. However, according to the national health policy, the primary health care level has the function of coordinating the care of people with chronic disease throughout the care network ${ }^{(1,4,19-20)}$, whereas this care should be continuous, prolonged and permanent ${ }^{(21)}$.

In this sense, given the diverse demands of long-term and continuous care, it can be seen that the child who lives with a chronic disease, in addition to receiving social support from family, neighborhood or friends, can receive different types of support from the multidisciplinary team of the primary, secondary, and tertiary levels of the health care network. Therefore, it is of fundamental importance that the primary care nurse has adequate preparation, participating in training courses or continuing education activities, in order to be aware of the situation of children and their families with chronic diseases. This can lead to it being one of the key components of the social support network, directing our attention to the structure of this network, as well as to the inter-sectorial relationships that help in the care of these children ${ }^{(6,9,17,19,22)}$. In general, without the support of health teams, families have weakened networks, and feel lonely and powerless to meet all demands at different stages of the disease. On the other hand, a study conducted in the United States shows that collaborative networks in caring for people with chronic diseases can transform care, as there is a collaboration of different actors in the process who understand that health care should be shared, valuing the knowledge of all involved, to develop a feeling of solidarity ${ }^{(23)}$.

Regarding the understanding that the social network approach is associated only with the issues of the child's socioeconomic and environmental context, it is important for nurses to integrate the knowledge of these aspects into their care routine, enabling humanized and individualized care. At the same time, they can provide guidance about available community resources to help the person know how to use them or to acquire them ${ }^{(24-25)}$.

According to the results of this study, children with chronic diseases are usually seen by physicians, revealing that in the context of primary health care, the focus on disease and procedures still prevails. These are characteristics of the biomedical care model, and the monitoring of these children when performed in the family health unit, is based on medical care, corroborating the results of other studies ${ }^{(26-27)}$. This fact points to the need for reorientation of the nursing care model in primary care, which should consider the comprehensive care provided to patients in their biopsychosocial and family context, whether in acute or chronic illness situations.

Comprehensiveness is a process that is currently under construction in primary health care; however, in relation to the care of children with chronic conditions, it is incipient and fragmented, requiring a change in the structure of services, and the qualification of professionals ${ }^{(18,26)}$.

Regarding the lack of articulation between the components of the health care network, studies show that the lack of integration between services, institutions, and professionals makes the continuity of care difficult, and increases the chances of recurrence of complications or unnecessary hospitalizations of children with chronic conditions $\mathrm{s}^{(11,18,22,28-30)}$. This fragility in care makes it impossible to effectively meet the real needs of the children receiving care.

From this perspective, when primary health care professionals do not offer resolute care, the family members seek other support networks that can meet their needs, assisting them in the care of the child ${ }^{(21)}$. Thus, these families come to rely on hospitals and emergency departments, even when faced with common childhood events, such as colds, fever, and other conditions.

A study on the organization of the flow of patients at different levels in the health system showed that primary health, in addition of being the system's gateway, must be linked with the 
different levels of care, seeking to minimize the difficulty of access for the population, and enable resolute and longitudinal care ${ }^{(31)}$.

In the practice of caring for children with chronic disease in primary care, difficulties related to the inefficiency of the referral and counter-referral system were evidenced, which is one of the major nodes for the continuity and longitudinality of care for this population. Similar difficulties have been identified in other studies on the challenges for the continuity of care for children with chronic conditions in health care network services ${ }^{(11,18,31)}$.

The difficulty of nurses in establishing a bond with the families of children with chronic diseases has also been emphasized, caused by their not attending the unit, and due to the lack of active search in their territory ${ }^{(18)}$. In this regard, a study on the care model that drove the care of children with chronic conditions in primary health showed that the community health agents are important allies for this care, due to the constant contact with families in their area, and because they are a link between these families and the health service ${ }^{(26)}$.

Given the problems in the organization of the work process of the family health team in the care for children with chronic diseases, studies demonstrate the need for clarity of the specific role of each category. Additionally, there is a need for better distribution of activities among professionals, so that they may be aware of their competences in caring for children/families living with any chronic disease, and help them from an inter- and multi-professional perspective $\mathrm{e}^{(32-33)}$.

However, in the practice of care, among family health strategy professionals, nurses have performed most of the administrative activities, which generate work overload and difficulty in establishing a bond with the population of their territory, as well as in the performance of their care functions. Therefore, discussions need to be fostered through continuing education activities among nurses so that they can feel safe, having the necessary skill and competence to provide support to families of children with chronic diseases, and thus to be an effective part of the network for these children / families.

\section{Study limitations}

This study has as a limitation the restricted number of participants, which cannot guarantee the generalization of results for all the Family Health Strategy teams in the cities of João Pessoa/ Paraíba and Rio de Janeiro/Rio de Janeiro. However, the research broadened the understanding of the factors implicated in the knowledge and practice of nurses of the primary health care network, regarding the approach of the network and social support for children with chronic disease and their families.

\section{Contributions to Nursing, Health or Public Policy}

This study reiterates the importance of nursing care aimed at supporting the families of children with chronic diseases, in order to improve the necessary support for the continuity of treatment, and the strengthening of inter-sectorial relationships and bonds established among the various members of the social network support.

Understanding the social context of the families receiving care, helps the primary care network professionals to improve interventions aimed at promoting child health, care management, as well as optimizing the care provided to children with chronic disease.

\section{FINAL CONSIDERATIONS}

The nurses participating in this study showed gaps in their knowledge of the social network theme, and reported limited and poor care practices, expressed by the difficulty in establishing bonds with the families of children with chronic diseases, and by the need to immediately refer these children to other professionals in the health care network.

The family health unit should be the priority place for monitoring the health status of these children, as these professionals have the opportunity to know their reality and their real needs and, therefore, have better conditions to coordinate the necessary actions for proper management of the disease.

The findings point to the need for development of a training course aimed at primary health care network nurses, so that they can use the tools of the social network methodological framework that provides for the optimization of care to families and children with chronic diseases and, consequently, the development of actions that contribute to autonomy and a better quality of life for this population group.

\section{REFERENCES}

1. Ministério da Saúde (BR). Secretaria de Atenção à Saúde. Departamento de Atenção Básica. Estratégias para o cuidado da pessoa com doença crônica. Cadernos de Atenção Básica, n.35 [Internet]. Brasília: Ministério da Saúde; 2014 [cited 2017 May 15]. Available from: http:// conitec.gov.br/images/pdf/Caderno_AtencaoBasica35.pdf

2. National Center for Health Statistics (NCHS). Health, United States, 2016: with chartbook on long-term trends in health. [Internet]. 2017 [cited 2017 Dec 15]. Available from: https://www.cdc.gov/nchs/data/hus/hus16.pdf

3. Instituto Brasileiro de Geografia e Estatística (IBGE). Pesquisa Nacional por Amostra de Domicílios: um panorama da saúde no Brasil, acesso e utilização dos serviços, condições de saúde e fatores de risco e proteção à saúde, 2008. [Internet]. Rio de Janeiro: IBGE; 2010 [cited 2017 May 15]. Available from: https://biblioteca.ibge.gov.br/visualizacao/monografias/GEBIS\%20-\%20RJ/panorama.pdf

4. Ministério da Saúde (BR). Secretaria de Atenção à Saúde. Departamento de Atenção Básica. Diretrizes para o cuidado das pessoas com doenças crônicas nas redes de atenção à saúde e nas linhas de cuidado prioritária. [Internet]. Brasília: Ministério da Saúde; 2013 [cited 2017 May 15]. Available from: http://bvsms.saude.gov.br/bvs/publicacoes/diretrizes\%20_cuidado_pessoas\%20_doencas_cronicas.pdf 
5. Cabral IE, Moraes JRMM. Family caregivers articulating the social network of a child with special health care needs. Rev Bras Enferm. 2015;68(6):769-76. doi: 10.1590/0034-7167.2015680612i

6. Silva MEA, Moura FM, Albuquerque TM, Reichert APS, Collet N. Network and social support in children with chronic diseases: understanding the child's perception. Texto Contexto Enferm. 2017;26(1):e6980015. doi: 10.1590/0104-07072017006980015

7. Nichols TR. Social Connectivity in those 24 months or less postsurgery. JWound Ostomy Continence Nurse. 2014;38(1):63-68. doi: 10.1097/ WON.0b013e318202a804

8. Sanicola L. As dinâmicas de rede e o trabalho social. 2a ed. São Paulo: Editora Veras; 2015.

9. Furtado LG, Nóbrega MML. Model of care in chronic desease inclusion of a theory of nursing. Texto Contexto Enferm. 2013;22(4):1197-204. doi: 10.1590/S0104-07072013000400039

10. Souza MHN, Nespoli A, Zeitoune RCG. Influence of the social network on the breastfeeding process: a phenomenological study. Esc Anna Nery Rev Enferm. 2016;20(4):e20160107. doi: 10.5935/1414-8145.20160107

11. Nóbrega VM, Silva MEA, Fernandes LTB, Viera CS, Reichert APS, Collet N. Chronic disease in childhood and adolescence: continuity of care in the health care network. Rev Esc Enferm USP. 2017;51:e03226. doi: 10.1590/s1980-220x2016042503226

12. Domenico CT, Castillo AMCM. Social support for the child with type 1 diabetes and their family. J Nurs UFPE On Line. 2017;11(12):5020-7. doi: 10.5205/1981-8963-v11i12a15211p5020-5027-2017

13. Araujo YB, Reichert APS, Vasconcelos MGL, Collet N. Fragilidade da rede social de famílias de crianças com doença crônica. Rev Bras Enferm. 2013;66(5):675-81. doi: 10.1590/S0034-71672013000500006

14. Minayo MCS. O desafio do conhecimento: pesquisa qualitativa. São Paulo: Hucitec; 2014.

15. Neves ET, Buboltz FL, Silveira A, Kegler JJ, Silva JH, Santos RP, et al. Rede de apoio de familiares de crianças em pronto atendimento pediátrico. Revista Pesquisa Qualitativa [internet]. 2017 [cited 2017 Dec 15];5(7):53-65. Available from: http://rpq.revista.sepq.org.br/index. $\mathrm{php} / \mathrm{rpq} / \mathrm{article} / \mathrm{view} / 74 / 63$

16. Okido ACC, Cunha ST, Neves ET, Dupas G, Lima RAG. Technology-dependent children and the demand for pharmaceutical care. Rev Bras Enferm [Internet]. 2016;69(4):671-7. doi: 10.1590/0034-7167.2016690415i

17. Pennafort VPS, Queiroz MVO, Nascimento LC, Guedes MVC. Network and social support in family care of children with diabetes. Rev Bras Enferm [Internet]. 2016;69(5):856-63. doi: 10.1590/0034-7167-2015-0085

18. Duarte ED, Silva KL, Tavares TS, Nishimoto CLJ, Silva PM, Sena RR. Cuidado à criança em condição crônica na atenção primária: desafios do modelo de atenção à saúde. Texto Contexto Enferm. 2015;24(4):1009-17. doi: 10.1590/0104-0707201500003040014

19. Souza MB, Rocha PM, Sá AB, Uchoa SAC. Trabalho em equipe na atenção primária: a experiência de Portugal. Rev Panam Salud Publica [Internet]. 2013 [cited 2018 Jan 04];33(3):190-5. Available from: https://www.scielosp.org/pdf/rpsp/2013.v33n3/190-195/pt

20. Mendes EV. A construção social da Atenção Primária à Saúde. Brasília: Conselho Nacional de Secretários de Saúde; 2015.

21. Belatto R, Araújo LFS, Dolina JV, Musquim CA, Corrêa GHLST. The family experience of care in chronic situation. Rev Esc Enferm USP. 2016;50(spe):78-85. doi: 10.1590/S0080-623420160000300012

22. Moreira MCN, Gomes,R, Sa MRC. Doenças crônicas em crianças e adolescentes: uma revisão bibliográfica. Ciênc Saúde Colet. 2014;19(7):2083-94. doi: 10.1590/1413-81232014197.20122013

23. Margolis PA, Peterson LE, Seid M. Collaborative Chronic Care Networks (C3Ns) to transform chronic illness care. Pediatrics. 2013;131 Suppl 4:S219-23. doi: 10.1542/peds.2012-3786J

24. Pacheco BP, Gomes GC, Xavier DM, Nobre CMG, Aquino DR. Dificuldades e facilidades da família para cuidar a criança com HIV/Aids. Esc Anna Nery Rev Enferm. 2016;20(2):378-83. doi: 10.5935/1414-8145.20160052

25. Moreira MCN, Albernaz LV, Sá MRC, Correia RF, Tanabe RF. Recomendações para uma linha de cuidados para crianças e adolescentes com condições crônicas complexas de saúde. Cad Saúde Pública. 2017;33(11):e00189516. doi: 10.1590/0102-311x00189516

26. Damasceno SS, Nóbrega VM, Coutinho SED, Reichert APS, Toso BRGO, Collet N. Children's Health in Brazil: orienting basic network to Primary Health Care. Ciênc Saúde Colet. 2016;21(9):2961-73. doi: 10.1590/1413-81232015219.25002015

27. Fernandes LTB, Nóbrega VM, Silva MEA, Machado AN, Collet N. Supported self-care for childrenand adolescents with chronic disease and their families. Rev Bras Enferm [Internet]. 2017;70(6):1318-29. doi: 10.1590/0034-7167-2016-0553

28. Allred E, An S, Leviton A, Loddenkemper T, McCrave J, Nichol SM. Should readmission within 30 days after discharge of children hospitalized for a neurologic disorder be considered a quality assurance failure? J Child Neurol. 2013;28(6):758-61. doi: 10.1177/0883073813481404

29. Coller RJ, Nelson BB, Sklansky DJ, Saenz AA, Klitzner TS, Lerner CF, et al. Preventing hospitalizations in children with medical complexity: a systematic review. Pediatrics. 2014;134(6):e1628-47. doi: 10.1542/peds.2014-1956

30. Cardoso TA, Roncada C, Silva ER, Pinto LA, Jones MH, Stein RT, et al. The impact of asthma in Brazil: a longitudinal analysis of data from a Brazilian national database system. J Bras Pneumol. 2017;43(3):163-8. doi: 10.1590/S1806-37562016000000352

31. Silva KS, Santos AM, Carvalho JA, Kochergin CN, Almeida PF. Percepção de gestores e enfermeiros sobre a organização do fluxo assistencial na rede de serviços de saúde. RECIIS Rev Eletron Comun Inform Inov Saúde. 2017;11(2):1-12. doi: 10.29397/reciis.v11i2.1226 
32. Salvador MS, Gomes GC, Oliveira PK, Gomes VLO, Busanello J, Xavier DM. Strategies of families in the care of children with chronic diseases. Texto Contexto Enferm. 2015;24(3):662-9. doi: 10.1590/0104-07072015000300014

33. Arantes LJ, Shimizu HE, Merchán-Hamann E. Contribuições e desafios da estratégia saúde da família na atenção primária à saúde no Brasil: revisão da literatura. Ciênc Saúde Colet. 2016;21(5):1499-510. doi: 10.1590/1413-81232015215.19602015 